\title{
IGE-RESISTIVITY MEASUREMENTS ON PARIS GLETSCHER, EAST GREENLAND
}

\author{
By M. C. Clark, * M. H. Key $†$ and G. J. Pert + \\ (Imperial College Exploration Board, Imperial College of Science and Technology, \\ London, S.W.7, England)
}

\begin{abstract}
D.C. ice-resistivity measurements on the polar Paris Gletscher in East Greenland are presented. It is found that the observed profile is well described by a four-layer system. Near the surface there are two layers resulting from the penetration of the summer temperatures into the polar ice. Below this the ice has constant resistivity until the bed is reached, where contrary to expectation a high-resistivity layer is found.

RÉsumé. Mesures de résistivité de la glace sur le Paris Gletscher, Groenland-Est. Les mesures de résistivité de la glace en courant continu sur le Paris Gletscher polaire situé dans l'Est du Groenland sont présentées. On a trouvé que le profil observé est bien décrit par un système à quatre couches. Près de la surface, on trouve deux couches résultant de la pénétration des températures estivales dans la glace polaire. Au-dessous, la glace a une résistivité constante jusqu'à ce que le socle soit atteint où, contrairement à ce qu'on pouvrait attendre, on découvre une couche de forte résistivité.

Zusammenfassung. Widerstandsmessungen im Eis des Paris Gletscher, Ost-Groenland. Gleichstromwiderstandsmessungen im Eise des polaren Paris Gletscher in Ost-Groenland werden vorgelegt. Es ergibt sich, dass das beobachtete Profil gut durch ein System von 4 Schichten beschrieben werden kann. Nahe der Oberfläche wurden 2 Schichten gefunden, die durch das Eindringen der Sommertemperaturen in das Polareis entstanden sind. Darunter hat das Eis bis zum Untergrund konstanten Widerstand. Wider Erwarten befindet sich dort eine Schicht mit hohem Widerstand.
\end{abstract}

Paris Gletscher is a medium-sized outflow glacier from the Greenland ice sheet (lat. $66^{\circ} 45^{\prime}$ N., long. $36^{\circ} 45^{\prime}$ W.) in the Angmagssalik district of East Greenland. The glacier flows through the mountains near Mont Forel down to the ice basin of Femstjernen (Fig. I). The glacier was inferred to be polar in character with only a small seasonal layer near the surface reaching freezing-point temperatures, as it was observed that there was no evidence of any subglacial drainage and that many crevasses were filled with water which did not drain away. The polar nature of the glacier was also indicated by the low value of ice resistivity found (Meyer and Röthlisberger, 1962).

Observations on the glacier were concentrated in an area on the east side of the valley north-west of Quervain Bjærg (Fig. I). In this area the surface was level transverse to the flow and it had a slope of about $3^{\circ}$ up-glacier. The surface was relatively crevasse-free with only small narrow crevasses less than $15 \mathrm{~cm}$ wide and $100 \mathrm{~m}$ apart being present. Measurements were made of the glacier flow and electrical resistivity (D.C.) during August I966 when the surface of the glacier consisted of a layer of loosely packed crystalline snow about $30 \mathrm{~cm}$ thick over waterlogged packed firn. Observations of ablation during the summer of 1966 and of net ablation over the year 1966-67 showed that the observation area was just below the firn line at the end of the ablation season in 1966.

Surface-flow measurements were made by observing the displacement of a grid of stakes drilled into the glacier. The stakes were surveyed from two stations established on rock on the east side of the glacier (Fig. I). Measurements were made over a ro-day period in August I 966 and the stakes were re-surveyed in August r 967 . The average velocities of the stakes during the summer of 1966 and the year $1966-67$ are given in Table I. The measurements indicate that apart from minor variations the flow down the glacier was uniform over the area of measurement, except for the eastern line 4, 8, I2, which shows retardation due to the rock

* Present address: Ontario Hydro, Toronto, Ontario, Canada.

$\dagger$ Present address: Department of Physics, Queen's University, Belfast, Northern Ireland.

¥ Present address: Department of Electrical Engineering, University of Alberta, Edmonton, Alberta, Canada. 


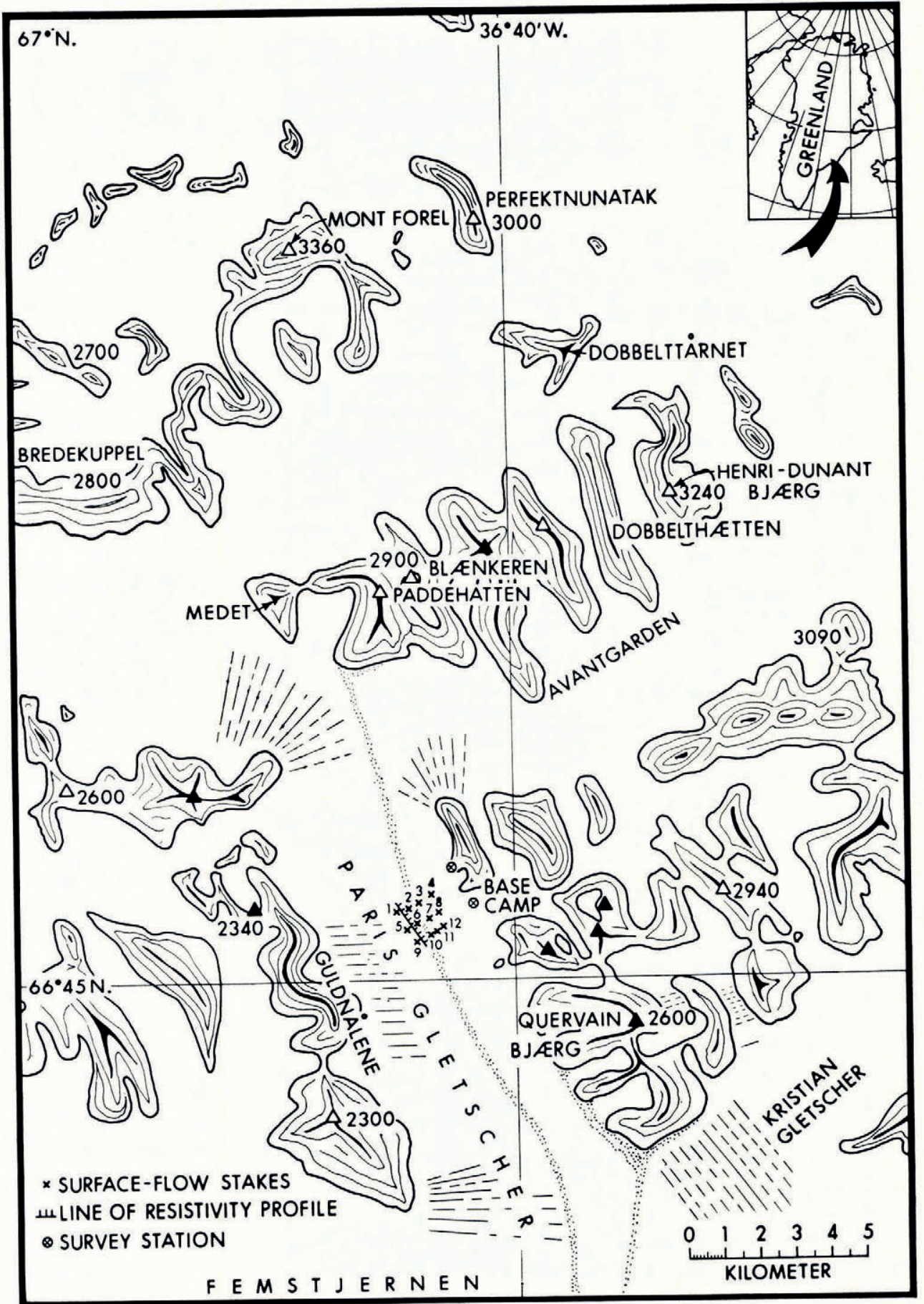

Fig. 1. Map of Paris Gletscher, East Greenland. The stakes used for the surface-flow studies were surveyed from the base camp and the station to the north. The resistivity profile was measured just east of the outermost stake line. 
Table I. Surface-flow Velocities Down-stream $(\mathrm{m} / \mathrm{d})$

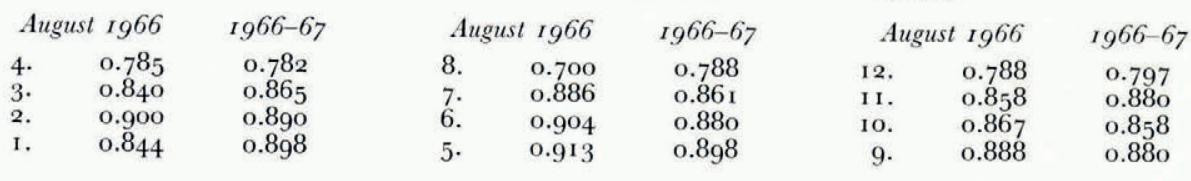

walls. The mean flow velocities for the year $1966-67$ show that there were no seasonal variations in the velocity, probably due to the fact that observations were made near the firn line on a polar glacier.

Ice resistivities were measured along a profile parallel to the prominent medial moraine about $200 \mathrm{~m}$ to the west. As the general techniques of ice-resistivity sounding have recently been discussed (Röthlisberger, I967), the basic details will not be given here. Current from a $720 \mathrm{~V}$ dry battery was passed through electrodes of $2 \mathrm{~cm}$ diameter dural tube hammered $30 \mathrm{~cm}$ into the underlying firn. The current was measured by a $5^{\circ} \mu \mathrm{A}$ Avometer and voltage on a battery-operated high-impedance valve voltmeter (Airmec type 3I4). An insulation check of the wiring showed that leakage currents were less than o.I $\mu \mathrm{A}$.

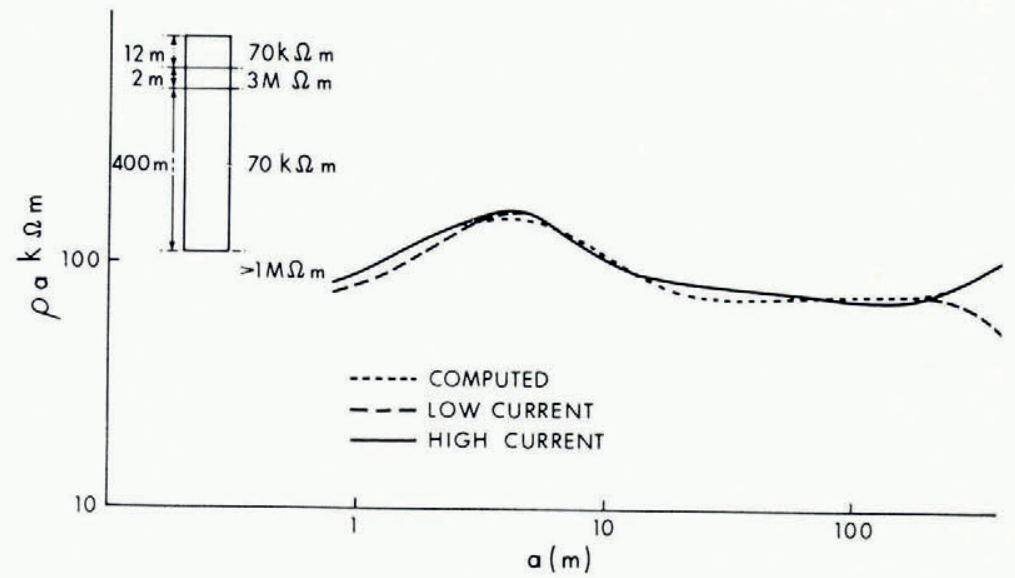

Fig. 2. The measured resistivity profile is shown both for the unsalted (low current) and salted (high current) electrodes. The deviation at large electrode separations is due to errors introduced by fuctuating ground potentials in the low-current case. Comparison is made with the computed curve for the four-layer system shown.

Ground potentials up to a maximum of $300 \mathrm{mV}$ were found. These were not steady but varied by as much as $20 \mathrm{mV}$ during an observation. In most cases the ground potential could be allowed for by making a measurement of its value before and after switching on and off the current. However, at large electrode separations the signal voltage was of the same size as the ground-voltage fluctuation. A series of readings was therefore taken with the current electrode region saturated with brine in order to increase the input current.

Measurements were made with the Wenner electrode system. The apparent resistivity/ electrode separation curve is shown in Figure 2. It can be seen that at large electrode separations there is a divergence between the results obtained with plain and electrolyte-immersed electrodes. The results with the large current obtained with brine-saturated electrodes are believed to give the correct curve as errors due to the fluctuations in ground potential were significant in the low-current case at this separation. The divergence at small separation was shown to be due to the surface conditions. In Table II measurements made with a wet snow 
surface during the day are compared with values from a frozen surface during the night. It can be seen that the resistivity of the frozen surface was significantly greater than that of the wet one.

TABle II. Apparent Resistivity $(\mathrm{k} \Omega \mathrm{m})$

$\begin{array}{ccc}\begin{array}{c}\text { Electrode separation } \\ \mathrm{m}\end{array} & \text { Wet surface } & \text { Dry surface } \\ \mathrm{I} & 78 & 85 \\ \mathrm{I} 22 & 65 & 7 \mathrm{I}\end{array}$

From Figure 2 it can be seen that the curve has three points of inflexion, indicating a fourlayer structure of the ice. The measured profile was compared with the set of master curves of the Compagnie Générale de Géophysique (1955). The transformation of the curves to the Wenner configuration was made using the factor I.4. * The best-fit four-layer curve is shown in Figure 2. The first layer, $12 \mathrm{~m}$ thick, is thought to be due to the waterlogged firn. The next layer, only $2 \mathrm{~m}$ thick but of high resistivity, is assumed to be ice at or just below freezing point; the high resistivity found is comparable with values obtained in measurements on temperate glaciers (Röthlisberger and Vögtli, r 967 ). The bulk of the ice has the typical low resistivity found in polar glaciers (Meyer and Röthlisberger, I962; Vögtli, I967). There is some evidence that the resistivity decreased slightly with depth but not to the extent found on ice sheets (Hochstein, I 967 ). At the base of the glacier, instead of the low resistivity expected of the rock bed $\left(\approx \mathrm{IO}^{4} \Omega \mathrm{m}\right)$, a layer of high resistivity $\left(>_{\mathrm{I}} \mathrm{M} \Omega \mathrm{m}\right)$ was found at a depth of about $420 \mathrm{~m}$. The origin of this layer was not understood but it is presumably the same feature as that found by Meyer and Röthlisberger (1962) in north-west Greenland. $\dagger$

The surface-flow results show that in the observation area the surface strain-rate was zero. In this case, Nye (1952) has shown that, provided the depth is much less than the glacier width, the surface velocity $\left(V_{\mathrm{S}}\right)$ in the centre of the glacier due to shear slip is given by

$$
V_{\mathrm{S}}=V_{\mathrm{b}}+\{k /(n+\mathrm{I})\}(\rho g)^{n} \sin ^{n} \alpha h^{(n+\mathrm{I})}
$$

where $\alpha$ is the surface slope of the glacier, $h$ the depth, $V_{\mathrm{b}}$ the bed-slip velocity, and $k$ and $n$ are the constant and exponent in Glen's law for ice shear (Glen, i955).

Unfortunately, as the bed-slip velocity $V_{\mathrm{b}}$ is not known, this relation cannot be used to give an accurate value of $h$. However, as $V_{\mathrm{S}}$ is a rapidly varying function of $h$, the value of the depth calculated from the above expression should be accurate to about $10 \%$ provided the proportion of bed slip contributing to the flow is less than $40 \%$.

Using the values of $k$ and $n$ found by Butkovich and Landauer (1958) for ice at $-5^{\circ} \mathrm{C}$, the depth of the glacier is found to be about $450 \mathrm{~m}$. There is a fairly large error in this result, however, as the slope of the glacier surface is only approximately known. Nonetheless, it does indicate that the identification of the high-resistivity layer at $400 \mathrm{~m}$ with the base of the glacier is justified, although the actual magnitude of the resistivity is considerably in excess of that anticipated for the rock bed.

The resistivity technique shows that Paris Gletscher is basically a four-layered structure. The first two layers to a depth of $14 \mathrm{~m}$ correspond to the seasonal variation in temperature near the surface. The bulk of the glacier is below freezing and has a conductivity much higher than that of the ice near the freezing point. At the base of the glacier a layer of high resistance is found, which is not thought to be due to the underlying bedrock.

* This factor is strictly valid only for the specific family of curves considered by Röthlisberger and Vögtli (1967). When used for other curves, it is only an approximation and there may be a constant multiplicative error in the depth scale.

$\uparrow$ Vögtli (1967) attributed the high-resistivity basal layer to the bedrock; as indicated above, the resistivity of the bedrock material (granite-gneiss) would appear to preclude such a possibility in this case, although there does appear to be considerable variability in the resistivity of the specific rock type. 


\section{Acknowledgements}

The work reported here was carried out during the 1966 and I 967 Imperial College East Greenland Expeditions. The authors would like to thank their colleagues on the expeditions for their help with these experiments. Thanks are also due to the bodies and individuals who supported and helped the expedition, in particular the Mount Everest Foundation, Imperial College Exploration Board, Royal Geographical Society and many others.

We should like to thank Dr H. Röthlisberger and Dr S. Evans for help in planning the experiments.

MS. received 12 October 1968

\section{REFERENCES}

Butkovich, T. R., and Landauer, J. K. 1958. The flow law for ice. Union Géodésique et Géophysique Internationale. Association Internationale d'Hydrologie Scientifique. Symposium de Chamonix, 16-24 sept. 1958, p. 318-27.

[Compagnie Générale de Géophysique.] 1955. Abaques des sondages électriques. Geophysical Prospecting, Vol. 3 , Suppl. 3 .

Glen, J. W. 1955. The creep of polycrystalline ice. Proceedings of the Royal Society, Ser. A, Vol. 228, No. I I75, p. $519-38$.

Hochstein, M. 1967. Electrical resistivity measurements on ice sheets. Fournal of Glaciology, Vol. 6, No. 47, p. $623-33$.

Meyer, A. U., and Röthlisberger, H. 1962. Electrical D.C.-resistivity measurements on glacier ice near Thule, Greenland. U.S. Cold Regions Research and Engineering Laboratory. Technical Report 87.

Nye, J. F. 1952. The mechanics of glacier flow. Fournal of Glaciology, Vol. 2, No. 12, p. 82-93.

Röthlisberger, H. 1967 . Electrical resistivity measurements and soundings on glaciers: introductory remarks. Journal of Glaciology, Vol. 6, No. 47, p. 599-6o6.

Röthlisberger, H., and Vögtli, K. 1967. Recent D.C. resistivity soundings on Swiss glaciers. Journal of Glaciology, Vol. 6, No. 47, p. 607-21.

Vögtli, K. 1967. D.C. resistivity soundings on Devon Island, N.W.T., Canada. Journal of Glaciology, Vol. 6, No. 47 , p. $635^{-42}$. 